\title{
KEGIATAN PENYULUHAN PADA IBU BALITA TENTANG PENTINGNYA IMUNISASI BAGI BATITA DI KP MARGAMULYA DESA CIKUNIR KECAMATAN SINGAPARNA TASIKMALAYA TAHUN 2018
}

OLEH :

\author{
ANNISA RAHMIDINI, S.ST., M.Keb. \\ (annisarahmidini@gmail.com) \\ CHANTY YUNIE, SST.,M.Kes \\ (chanty.yunie@gmail.com)
}

\section{A. DASAR PEMIKIRAN}

Imunisasi dalam sistem kesehatan nasional adalah salah satu bentuk intervensi kesehatan yang sangat efektif dalam upaya menurunkan angka kematian bayi dan balita. Dasar utama pelayanan kesehatan, bidang preventif merupakan prioritas utama, dengan melakukan imunisasi terhadap seorang anak atau balita, tidak hanya memberikan perlindungan pada anak lainnya, karena terjadi tingkat imunitas umum yang meningkat dan mengurangi penyebaran infeksi (Ranuh dkk, 2011).

Imunisasi dasar adalah pemberian imunisasi awal pada bayi untuk mencapai kadar kekebalan di atas ambang perlindungan (Depkes RI, 2012). Jenis- jenis imunisasi dasar, yaitu: BCG, yaitu imunisasi dasar yang diberikan untuk mencegah penyakit TBC. Kemudian imunisasi dasar Hepatitis B, yang diberikan untuk mencegah penyakit hepatitis B. Selanjutnya DPT, yaitu imunisasi dasar yang diberikan untuk mencegah penyakit difteri, pertusis, dan tetanus. Kemudian imunisasi dasar Campak, yang diberikan untuk mencegah penyakit campak dan yang terakhir imunisasi dasar Polio, yang diberikan untuk mencegah penyakit polio (IDAI, 2014).

Salah satu dari 8 tujuan MDGs pada poin keempat adalah menurunkan angka kematian bayi dengan meningkatkan status imunisasi terutama imunisasi dasar lengkap pada bayi karena imunisasi merupakan hal yang wajib untuk melindungi bayi dari penyakit yang kerap menyerang. Namun, cakupan imunisasi dasar masih di bawah target (Priyono, 2010). 
Cakupan imunisasi dasar di Desa Cikunir sudah mencapai angkat 80-90\%, akan tetapi target cakupan imunisasi dasar yaitu 100\% sehingga seluruh batita yang ada di Desa Cikunir mendapatkan imunisasi dasar. Untuk meningkatkan cakupan target tersebut perlu adanya kesadaran dari ibu yang memiliki batita untuk dapat membawa batitanya ke posyandu sehingga mendapatkan imunisasi dasar sesuai dengan jadwal pemberiannya.

Berdasarkan hal tersebut maka perlunya dilakukan penyuluhan kepada ibu yang memiliki batita tentang pentingnya imunisasi dasar dan jadwal imunisasi, sehingga setiap batita mendapatkan imunisasi dasar lengkap.

\section{B. TUJUAN KEGIATAN}

Adapun tujuan dari kegiatan ini adalah

1. Meningkatkan pengetahuan ibu yang memiliki balita tentang pentingnya imunisasi pada batita (bayi usia dibawah tiga tahun)

2. Meningkatkan pengetahuan ibu balita tentang jadwal pemberian imunisasi pada batita.

\section{SASARAN}

Kegiatan pendidikan kesehatan (penyuluhan) kesehatan mengenai pentinya imunisasi pada batita ditujukan pada ibu yang memiliki batita (bayi dibawah tiga tahun) di kampung Margamulya Desa Cikunir Kabupaten Tasikmalaya

\section{WAKTU DAN TEMPAT PELAKSANAAN}

Kegiatan dilakukan dari tanggal 27 September 2018, bertempat di Kp Margamulya Desa Cikunir Kec Singaparna Kab Tasikmalaya.

\section{E. HASIL KEGIATAN}

Adapun pelaksanaan kegiatan yang dilakukan sebagai berikut:

1. Persiapan

a. Dilakukan survey sasaran dengan melibatkan kader setempat

b. Pengurusan ijin

c. Pengurusan administrasi (surat menyurat)

d. Persiapan alat dan bahan serta akomodasi

e. Persiapan tempat yaitu di Madrasah Aliyah Dusun Margamulya.

2. Pelaksanaan kegiatan penyuluhan

a. Pembukaan dan Perkenalan dari mahasiswa kepada peserta

b. Pre test untuk mengetahui sejauh mana ibu mengetahui tentang imunisasi dasar dan jadwal pemberian imunisasi.

c. Penyuluhan kepada ibu yang memiliki batita tentang pentingnya imunisasi 
dasar dan jadwal imunisasi.

d. Sesi diskusi dan Tanya jawab kepada peserta

e. Post test tentang imunisasi dasar dan jadwal pemberian imunisasi.

3. Penutupan

a. Pengumuman hasil pre dan post test kepada peserta

b. Foto bersama dengan peserta penyuluhan

c. Berpamitan dengan pengurus dan peserta

d. Pembuatan laporan kegiatan pengabdian masyarakat

\section{Output}

Output yang didapat dari kegiatan pengabdian masyarakat ini diantaranya adalah :

a. Ibu yang memiliki batita diberikan pendidikan kesehatan (penyuluhan) mengenai jenis-jenis imunisasi, manfaat dari masing-maisng imunisasi dasar dan jadwal pemberian imunisasi.

b. Dari hasil penyuluhan, ibu memahami mengenai isi materi dan di akhir sesi diberikan waktu tanya jawab. Didapatkan beberapa pertanyaan dari remaja diantaranya : a. Bagaimanakah caranya jika ada imunisasi dasar yang sudah terlewat waktunya? b. Bolehkah anak meminum obat penurun panas setelah bayi diberikan imunisasi?

c. Untuk mengevaluasi tingkat pemahaman ibu terhadap isi materi penyuluhan, maka dilakukan pre dan post test yang hasilnya terjadi peningkatan pengetahuan ibu tentang imunisasi dasar dan jadwal imunisasi.

\section{Outcome}

Outcome yang didapatkan diantaranya adalah :

a. Dengan adanya program pengabdian masyarakat yang berupa penyuluhan mengenai pentingnya imunisasi dasar dan jadwal imunisasi, cakupan target imunisasi dasar di Desa Cikunir dapat meningkat sesuai target.

b. Diharapkan dengan kegiatan penyuluhan tersebut ibu yang memiliki batita memiliki kesadaran untuk membawa batitanya ke Posyandu setiap kali jadwal imunisasinya.

c. Diharapkan STIKes Respati semakin dikenal dan terdepan dalam membantu dalam meningkatkan kepedulian terhadap permasalahan masyarakat khususnya pencapaian target imunisasi dasar yang ada di wilayah Kabupaten Tasikmalaya.

\section{F. DAFTAR PUSTAKA}

Ranuh,I.G.N.2011. Pedoman Imunisasi di Indonesia. Edisi ketiga.Jakarta: Badan Penerbit Ikatan Dokter Anak Indonesia

Peraturan Menteri Kesehatan Nomor : 1611/MENKES/SK/XI/2012 tentang Pedoman Penyelenggaraan Imunisasi.Jakarta: Departemen Kesehatan Republik 
Indonesia

Priyono, Y. (2010).Merawat Bayi Tanpa Baby Sitter.Yogyakarta: Medika Pressindo.

Proverawati, A, dkk. (2010). Imunisasi dan Vaksinasi. Yogyakarta: Nuha Offset.

Achmadi, U.F. (2006). Imunisasi Mengapa Perlu?. Jakarta: PT Kompas Media Nusantara.

\section{G. DOKUMENTASI}

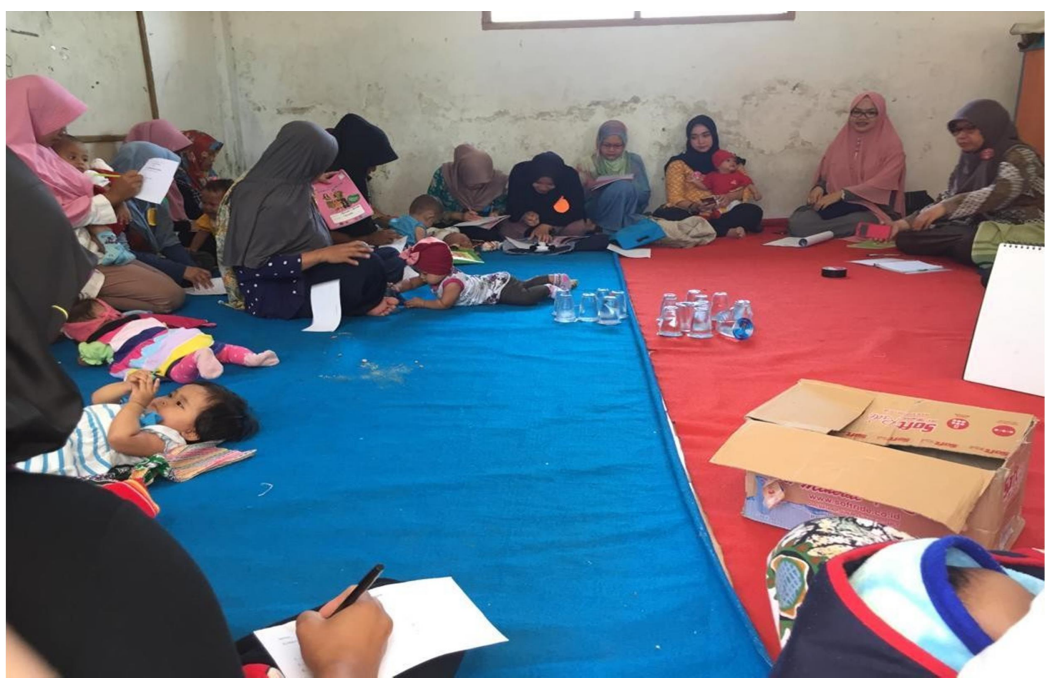

